Бојана М. ВЕЉОВИЋ*

Универзитет у Крагујевцу

Филолошко-уметнички факултет
Оригинални научни рад

Примљен: 5. 10. 2020.

Прихваћен: 25. 2. 2021.

\title{
КОНСТРУКЦИЈЕ СА ГЛАГОЛИМА БИТИ И ХТЕТИ У ДИЈАЛЕКТИМА СРПСКОГ ЈЕЗИКА
}

\begin{abstract}
У раду се анализирају конструкције сложене од бити и хтети у првом и допунских глагола у другом делу. У конструкције са глаголом бити убрајамо: а) аорист глагола бити + императив; б) перфекат глагола бити + инфинитив. Глагол хтети у имперфекту бележимо у трима конструкцијама које, иако облички истоветне, имају различита значења. Све конструкције дијалекатског су карактера, али нису својстене свим народним идиомима. Ареална распрострањеност условљена је системским статусом облика што учествују у њиховом грађењу - имперфекта, инфинитива. Говори у којима су ови глаголски облици у процесу нестајања или су пак ишчезли не знају ни за конструкције од њих творене, док их идиоми у којима је њихов статус стабилан познају.

Кључне речи: сложене глаголске конструкције, модалност, би + императив, било + инфинитив, шћаше + инфинитив.
\end{abstract}

\section{0. Увод}

У раду се анализирају сложене конструкције са глаголима бити и хтети у првом и допунским глаголима у одговарајућој морфолошкој форми у другом делу. Ови глаголски облици немају својега имена иако се у дијалектима који их познају употребљавају увек у истој, морфолошки јасно дефинисаној форми и са сасвим специфичним значењем. Иако се исказана глаголска радња везује увек за одређену временску сферу на темпоралној линији, у први план истакнуто је неко од модалних значења, те их стога можемо сматрати примарно модалним глаголским облицима.

Међу конструкцијама са глаголом бити издвајамо оне творене од: а) аориста глагола бити и императива и б) перфекта глагола бити и инфинитива. Глагол хтети у имперфекту бележимо у трима формално идентичним

\footnotetext{
"bojana.veljovic@filum.kg.ac.rs
} 
- шћаше + инфинитив / да + презент - али семантички разнородним конструкцијама.

Фреквентност конструкција са глаголима бити и хтети различита је - у говорима зетско-сјеничког и херцеговачко-крајишког дијалекта често се бележе, док се у описима шумадијско-војвођанских и косовско-ресавских говора готово уопште не помињу. У идиомима призренско-тимочке зоне јављају ce, у унеколико измењеном морфолошком виду (због непостојања инфинитива), семантички истоврсне конструкције. Њихово (не)постојање у српским говорима свакако је у вези са системским статусом имперфекта и инфинитива, те је тако и очекивана њихова висока фреквентност у јекавским говорима, те, с друге стране, смањен обим употребе или потпуно изостајање на остатку територије. У разговорном стилу савременог српског језика оне потпуно изостају, па их сматрамо дијалекатски маркираним и архаичним формама. У овоме раду у анализи крећемо од грађе прикупљене на терену говора Тутина, Новог Пазара и Сјенице, ${ }^{1}$ из које издвајамо примере са поменутим конструкцијама, на основу којих испитујемо њихове синтаксичко-семантичке и морфолошке особине. Прилике у датом говору поредимо са стањем у другим штокавским говорима, и то на основу података до којих долазимо на основу расположивих студија. ${ }^{2}$

\section{1. Конструкције са глаголом бити}

На терену тутинско-новопазарско-сјеничког говора забележили смо два типа конструкција са глаголом бити: било + инфинитив и би + императив.

\footnotetext{
${ }^{1}$ Истраживањем је обухваћено укупно 105 пунктова, од којих је 51 село на територији тутинске општине. Наводимо њихов списак и скраћенице које су коришћене у раду:

Баћица (Ба), Биохане (Би), Блаца (Бл), Бороштица (Бо), Брегови (Бр), Врба (Вр), Врујца (Вру), Глухавица (Гл), Глоговик (Гло), Годово (Го), Гурдијеље (Гу), Делимеђе (Де), Детане (Дет), Добри Дуб (Д. Дуб), Добриња (До), Долово (Дол), Дулебе (Ду), Ђерекаре (Ђер), Ервенице (Ер), Жирче (Жи), Жупа (Жу), Кељепоље (Ке), Коваче (Ков), Кониче (Кон), Кочарник (Коч), Лескова (Ле), Липица (Ли), Мелаје (Ме), Митрова (Ми), Набоје (На), Островица (Ост), Паљево (Па), Пероше (Пе), Пленибабе (Пл), Попе (По), Пресло (Пр), Пружањ (Пру), Рамошево (Рам), Рачиће (Рач), Рудница (Руд), Руђа (Ру), Саш (Са), Сврачиће (Св), Смолућа (См), Старчевиће (Ст), Струмце (Стр), Суви До (С. До), Тутин (Ту), Црниш (Цр), Шароње (Ша), Шипче (Ши).

У Новом Пазару обишли смо 26 пунктова:

Багри (Баг), Балетиће (Бал), Бобовик (Боб), Боторовина (Бот), Брђани (Брђ), Вучја Локва (В. Лок), Избице (Из), Јошаница (Јо), Јуковача (Ју), Кашаљ (Ка), Козарево (Коз), Лече (Леч), Лукаре (Лу), Неготинац (Не), Нетврђе (Нет), Осоје (Oc), Пожега (Пож), Прћенова (Прћ), Рајетиће (Ра), Рајчиновиће (Рај), Себечево (Се), Сопоћани (Со), Суха Ћуприја (С. Ћуп), Трнава (Трн), Цвијетње (Цв), Шавце (Шав).

Сјеничких пунктова је 23:

Баре (Бар), Бољаре (Бољ), Буђево (Бу), Врсјенице (Врс), Градац (Гр), Гошево (Гош), Дражевиће (Др), Дубница (Дуб), Дуга Пољана (Д. Пољ), Дујке (Дуј), Зајечиће (За), Карајукића Бунари (К. Бун), Кијевце (Ки), Кладница (Кл), Кнежевац (Кн), Тузиње (Туз), Угао (Уг), Цетановиће (Це), Црвско (Цр), Чедово (Че), Шаре (Шар), Штаваљ (Шт), Шушуре (Шу).

${ }^{2}$ Овде се ограђујемо од давања изричитих тврдњи о (не)постојању неког облика у појединим говорима или дијалектима и то стога што је синтаксички ниво српских говора недовољно истражен и описан.
} 


\section{1. Било + инфинитив}

Јавља се увек у истом облику - крњи перфекат глагола бити у безличној форми и инфинитив допунског глагола, који није заменљив конструкцијом $\partial a+$ презент. У питању је модална конструкција која се позиционира на претериталну временску линију, тј. глаголом означена радња припада сфери прошлости. Њоме се, у најширем смислу, исказује у прошлости не(из) вршена радња, али таква да ју је, оцењено са становишта говорног лица, одговарајући субјект требало / морао (из)вршити, и то управо стога што су услед њенога не(из)вршења наступиле последице које су могле / морале бити спречене, тј. које је требало спречити. Наведено важи онда када је у питању форма са потврдним обликом глагола бити: Било чуват паре, па би сад имали (= требало је да чувате...; морали сте чувати...). Када се употреби негирани облик, важи исто: Не било лагат, па те не би уфатили у лаж (= није требало да лажеш...).

Модална компонента а) морања, односно требања у прошлости у првом је плану када је реч о семантици овог сложеног облика али није и једина присутна; говорно лице такође изриче и: б) став личног неслагања са датом чињеницом, обликован кроз наглашену нијансу прекора због (не)вршења акције; а неретко се препознаје и в) став ликовања због последица које су уследиле. У примеру који је мајка изговорила детету које се пожалило да га је млађи брат ударио: Не било га дират, па те не би ударио - имамо и прекор, али и имплицитну поруку: 'нека те је ударио, није требало да га изазиваш', као неку врсту слагања са последицом која је уследила, и то стога што она има послужити као наук за будуће (боље, исправније) поступање или понашање. У питању је догађај који има вредност опомене, упозорења, 'животне школе', кроз личну грешку стечене поуке.

Забележили смо конструкције са потврдним формама глагола бити (1), и оне са негираним облицима (2):

(1) би́ло ште́дет пӓре, па̄ нё би жӣвёл'и пот кирӥју (Ле); би́ло мйслит за ко̄гӓ ће да се уда̂, нё би сӓд би́ла на мӱку (Пе); би́ло ӱчит, сӓд нё би пона̄вљоิ (Bp);

(2) јӓко те убйо, нё бйло га ди́рат (Бал); нё бйло трӧшит, сӓд би имӓл'и пӓре (Жи); нё бйло се пеิт на тӓван и пӓднут, сад нё би л’ежӓла с полӧмљено̄м ногоิм (По). ${ }^{3}$

Када је последица позната из ширег контекста, експлициран је само део исказа са помоћним глаголом: би́ло ште́dem (= као одговор на причу о изненадној немаштини).

О конструкцији коју анализирамо доста је писано у србистичкој литератури. Љ. Стојановић истиче да се „инфинитив с партиципом претерита другим од глагола бити може употребити место претерита одречно-упитних

\footnotetext{
${ }^{3}$ Д. Барјактаревић у студији о новопазарско-сјеничким говорима (Барјактаревић 1966) ову конструкцију не помиње, иако наша грађа показује да је заступљена у свим пунктовима поменуте територије.
} 
реченица, којима се више укорава или окривљује него што се пита" (Стојановић 1921: 205). Ј. Вуковић потцртава присуство семантичких компонената прекора и окривљавања, те допуњава став Љ. Стојановића, истичући у првом реду присуство наглашеног прекоревања, с тим да ипак „нијансирање израза у смислу питања долази само по себи као секундарна појава у језичком осећању, - и зато израз и не може добити смисао правог питања" (Вуковић 1954: 263, 264). Значајно за расветљавање семантичке природе конструкције са глаголом бити јесте и истраживање Љ. Поповић, у чијем се раду утврђује да, сем што је широко распрострањена у српском, ова конструкција често се употребљава и у хрватском, пољском, украјинском и староруском језику, што „наводи на помисао да је у питању архаична општесловенска конструкција са модалним глаголом бити и инфинитивом у служби предиката" (Поповић 2019: 206). Конструкција бити + инфинитив, како наводи ауторка након анализе примера из различитих идиома српског језика, „спада у тип контрафактивне деонтичке” конструкције, а „по својим карактеристикама она је слична контрафактивном плусквамперфекту” (Исто). Реч је о „хибридној конструкцији, која је исказана персоналним и имперсоналним обликом крњег перфекта или имперфекта, при чему се персоналним обликом глагола бити исказује интерно оријентисана модалност, а имперсоналним - екстерна. У конструкцији долази до прожимања темпоралног и модалног граматичког значења, тако да је модално доминантно, а темпорално - рецесивно. Проблем функционалног споја временског облика плусквамперфекта и деонтичке модалности разрешава реинтерпретација темпоралности као контрафактивне, што је преводи у иреалис. Контрафактивне деонтичке конструкције описују догађај који је, по говорниковом мишљењу, требало иницирати саговорнику или трећем лицу како би дошло до другачијег развоја ситуације, описане у другом делу конструкције или исказане контекстуално" (Исто, 216).

М. Пешикан прихвата став J. Вуковића да се конструкцијом типа бијо доћ казује „требање у прошлости” насупрот Маретићевог „морања у прошлости” (Пешикан 1965: 204). И у староцрногорским говорима „овим обликом се (кад је у потврдној форми) казује радња коју је требало да врши или изврши субјекат у сопственом интересу (односно у интересу остварења својих намера); а за одречну форму дефиниција је супротна. Отуда уз овај облик обично (кад год се то не подразумева из контекста) стоји реченица којом се казује шта би се постигло (или избегло) да је субјект друкчије по-

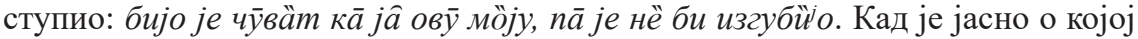
је радњи реч, инфинитив у овој конструкцији може и изостати: а тиि нё бијо" (Пешикан 1965: 204). Као што се из изложених примера види, конструкција није бележена у безличној форми са било, већ је глагол бити увек у личном облику. За говор Враке Д. Петровић наводи да се перфектом глагола бити и инфинитивом означава прекор, а из примера се види да је глагол бити у личном облику: Нё бйла се свӓђ $\bar{m}$, па би била мирнйја̄ (Петровић 1974: 175). Б. Милетић је бележи у црмничком говору: бӥјо прӓ(в)о збӧрит, па̄ те нё би нӥко клёо (Милетић 1940: 555). 
М. Николић за говор Горобиља наводи: „Јавља се крњи перфекат глагола бити са инфинитивом у значењу 'требало је да': Бӥо бӥти пӧn! - каже се ономе ко се жали на тежак посао, тежак живот уопште" (Николић 1972: 700). У говору источне Херцеговине јавља се са личним облицима глагола бити у потврдној и негираној форми, а А. Пецо такође подвлачи присуство нијансе прекора: бӥјо у̀ранит па не би за̀каснијо (Пецо 2007: 271). У говору Колашина јављају се два типа: а) тип био доћи: бӥјо у̀чит на̀ вакат и б) тип било + инфинитив, који може се чути, можда чак чешће од претходног: осиро̀машйли су - би́ло ра́дит (Пижурица 1981: 210). Ј. Вуковић у опису говора Пиве и Добњака наводи да спој био радити ипак треба сматрати обликом требања у прошлости, а не, како Т. Маретић одређује, обликом морања у прошлости - „то је у ствари једна врста потенцијала - иреалног - за прошлост": бијо ра́dит ко ѝ мй, nā б’ùмō (Вуковић 1940: 99). За ускочки говор се такође констатује њено постојање у форми био доћи (Станић 1977: 85-86). М. Станић посвећује више пажње анализи, те закључује да ако је овај облик употребљен у простој реченици, онда та реченица увек долази као одговор на оно што је саговорник рекао у претходној реченици: А. У̀мрu'eћy о̀ же̄ђе̄. Б. Би́ла по̀ни'ет бӧиу во̀де. Иначе би те реченице, без оваквог контекста, гласиле: Би́ла по̀ни'ет бӧиу во̀де, па сӓд нѐ би ӱмирала о̀ же̄ђе̄ (Станић 1977: 100). М. Станић се слаже са обама одређењима присутнима у литератури - и требање и морање у прошлости може се прихватити као значењска компонента (Станић 1977: 100). М. Тешић конструкцију бележи у говору Љештанског (Тешић 1977: 244).

У говорима призренско-тимочке зоне, услед непостојања инфинитива, ова конструкција није могућа у устаљеном свом лику. Но, као семантички подударна бележена је у говору Бучума и Белог Потока конструкција било $+\partial a$ + презент и то са значењем „требало је”: било́ да се не обś́maш на тој ки́че (= ваљало је да не окрећеш пажњу ка том човеку) (Богдановић 1979: 124). У говору Лужнице забележени су примери модалног, жељног плусквамперфекта, у којима се поред жеље да се изврши оно што се њима казује осећа и нијанса жаљења због пропуста да се учини што је требало: ма́кар какви́ шко́лииу да бе́ше заврши́л; са, као што се види, имперфектом глагола бити и радним глаголским придевом (Ћирић 1983: 106).

У студијама о говорима шумадијско-војвођанског, смедеревско-вршачког и косовско-ресавског дијалекта ова конструкција није бележена.

\section{2. Би + императив}

Конструкција сложена од аориста глагола бити (са обликом би за сва лица) и императива ${ }^{4}$ јавља се увек у јединственој форми и са јединственим, специфичним значењем. Њоме се обележавају вишекратне радње у прошлости понављане по утврђеном редоследу, обичају или навици. У истој служби у тутинско-новопазарско-сјеничком говору употребљавају се наративни

${ }^{4}$ Детаљније у: Вељовић 2015. 
потенцијал и императив, те, са нешто мањом учесталошћу, наративни презент. Они су, у контекстима овога типа међусобно заменљиви без измене значењских и стилских момената. При употреби сваког од наведених облика присутне су, сем семантике прошлости, и додатне значењске компоненте емотивности, евокативности и доживљености, с тим да су најизраженије при употреби потенцијала, имајући у виду да су то и примарни елементи његове семантичке структуре (Ивић М. 1983: 44).

Употребљава се у потврдној (3) и, ређе, у негираној (4) форми, и најчешће се у ширим контекстима комбинује са семантичким конкурентима наративним потенцијалом и императивом:

(3) па би йшљи у кољеда́ре, то би мй ӧмладина скӱпи се и понӧћи би ӥшљи от кӱће̄ до кӱће̄ и тра́жи ко шта ӥма̄, мӓсла, сйра, брӓшна, тоิ свё кад би скӱпиљи на едно мёсто налӧжи вӓтру и то̄ би спре́ми и

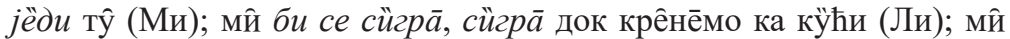
ни́смо држӓљи бйвољйцу, ӧни ни́су држӓљи сви́њу и мй би код њй јёди, пй, пла́сти, жниิ (Жи); с кӧн'има би оти́ди и довёди је (Ђер);

(4) ӧни се спр̈ва ни́су мӣрйљи, мӧжда и би по пӧла гӧдине̄ прӧшло нё би се поми́ри (Не); којаิ би побёгла дӱже̄ врёмена не би јој се поми́ри роิт од иња́та што нйе са ра̄зилу̀ком рӧда она даิта, но е сӓмовол'но отӥшла, сӓмовол'но побёгни и ӧни се посвӓди (Па).

У литератури се за конструкцију би + императив усталио назив хабитуал (в. Халиловић 1985: 51-55; Грицкат 1998: 38; Окука 2008: 77, 290; Брозовић 1958: 346 и др.). До сада се углавном везивала за говоре који су изван граница Републике Србије. П. Ивић је помиње у вези са говорима на простору између доњих токова Дрине и Босне, где се употребљава и у говору хришћанског и у говору муслиманског становништва (Ивић 2001: 188). У источнобосанском поддијалекту херцеговачко-крајишког дијалекта употребљава се хабитуал мй би рѐци (Окука 2008: 77). Иста конструкција у употреби је у приповедању у говорима у средњој Рами: сйнко, оิн би рѐuฺн; и у Лашви: па би јој ја̄ оेтка̄j (Окука 2008: 290); у долини реке Фојнице (Брозовић 1958: 346), Паклареву код Травника (Ваљевац 1990, цит. према: Лучић 2008: 11), а има је и у књижевноуметничком регистру савременог босанског језика (Ибришимовић 2011: 35).

Конструкцију би + императив Сенахид Халиловић назива бх. хабитуалом, који је најприсутнији у говору стариначког муслиманског становништва, што наводи на закључак да је реч о аутохтоној особини старије провинијенције (Халиловић 1985: 53).

У неким говорима зетско-сјеничког дијалекта у Црној Гори сличну службу врши спој глагола хтети и императива - ћax + приповедачки императив (Пешикан 1965: 206), односно (u)ћаше + императив (Ћупић 1977: 172). Конструкцијом $\hbar a x+$ императив казују се радње које су се понављале у прошлости: ћа̄ще ӥди, ћа̄mе донӧси (Пешикан 1965: 206). У говору Бјелопавлића конструкција (w)ћаше + императив бележена је у примерима типа: Маркко вӓзда кат при́ми ивали́ду ћаิше ђёции донёси бо борнаิ и чокола̄де̂ (Ћупић 1977: 


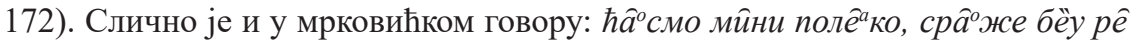
ком (Вујовић 1969: 345). У говору никшићке зоне присутна је конструкција шћаше + 2. лице једнине императива (шћаше он дођи) ${ }^{5}$ (Халиловић 1985: 51).

Уколико се вратимо питању разлога постојања конструкције са специјализованим значењем у говору Тутина, Новог Пазара и Сјенице, поред два већ постојећа облика који се употребљавају за исказивање хабитуалности, можемо претпоставити следеће: а) да је њено постојање у језику узроковано прагматичком потребом за стварањем језичког средства специјализованог за исказивање искључиво семантике протеклог понављања; б) да њено упориште налазимо у већ постојећем систему сложених конструкција са специјализованим значењем (које овде анализирамо); в) да је, судећи по фреквенцији

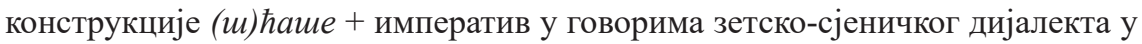
Црној Гори, која се употребљава у хабитуалној или квалификативној служби, би + императив у тутинско-новопазарско-сјеничкој зони истиснуо из употребе сличну конструкцију - шћаше + инфинитив, која се данас користи у овом говору само у квалификативној служби; г) да није искључено да је реч о старој конструкцији која у овом говору досада није откривена, а која, узимајући у обзир непотпуност синтаксичких података у дијалектолошкој литератури, није искључено да постоји у још неким другим идиомима; д) да се постојањем ове конструкције говори тутинско-новопазарско-сјеничке зоне повезују у мање-више јединствен и непрекинут ареал са говорима на територији ЦГ и БиХ.

\section{2. Конструкције са хтети}

У наставку анализирамо сложене конструкције са глаголом хтети и инфинитивом (коме је конкурентна конструкција $\partial a+$ презент), које су морфолошки једнаког састава, али различитог значења, које зависи од (изван)језичког контекста.

\section{1. Хтети + инфинитив / да + презент са значењем иреалног потенцијала / кондиционала за прошлост}

Перифрастична конструкција са имперфектом глагола хтёт / wћёm употребљава се да се њоме обележи радња која се, иако су за то постојали реални услови, у прошлости није (из)вршила, и то у контекстима типа: $и \hbar a-$ ше ирћ од жеђи да му не донијех воде. Неповољна ситуација која је могла уследити исказује се у главној, а радња која је довела до њеног спречавања у зависној реченици. Не(из)вршење глаголске радње од стране говорног лица на прагматичком плану истиче се као позитивна, повољна, тј. срећна околност ('добро је што се то и то није догодило') јер би последице у супротном биле веома неповољне за лице о коме је реч.

\footnotetext{
${ }^{5}$ Аутор је назива никшићким хабитуалом (Халиловић 1985: 51-52).
} 
У грађи су забележени примери у којима су експлициране и не(из)вршена радња и оно што ју је спречило (5), али и они без експлицираног другог дела, који се може лако препознати из контекста (6); примери са $\partial a+$ презент уместо инфинитива (7):

(5) шћáme је и ӱбит да и не раздвӧји (Го); шћámе свё ово̄ растӥрит да му дӓдосмо (Ту); она се шћа́ше рӓзвес од њёга, да хи не помйрӣсмо (Ле); wћâ све оно̄ попа́л’ит да погорй да ме не уфӓтйше (По);

(6) ићâ пӓнут на она̄ л’еิт (По); шћа́ше погйнуm за њо́ме (Ме); шћâ да препӱкнемм од плӓча (Ту);

(7) jā $u \hbar a ̂$ нӓмртво да га убйје̄eм да га не одбра̄нйше (Bp); шћáme дa погӥне тӓмо ра̄де́ћи да нё уфати кйша (Пе); ића́ше глаิву да изгйбй за њо́ме (Не).

Како истиче Ј. Вуковић, конструкција творена од глагола хтети и инфинитива употребљава се за исказивање различитих нијанси модалних значења, која у извесном смислу има „вредност која по значењу одговара кондиционалу (потенцијалу)" (Вуковић 1967: 48).

У староцрногорском говорима спој ћаx + инфинитив употребљава се као потенцијал за прошлост у разним нијансама: ћаิх умрйјет да нё до̄ђе дӧктор (Пешикан 1965: 206); бележена је и у говору Црмнице: да нё беше түิна овӥја љу $\bar{\jmath}$, ћаิше злӧ бӥт (Милетић 1940: 55). Д. Барјактаревић је илуструје потврдама: ӧћа̄ще погйнӯm да не стӥгосмо; jā mи шћâ дӓm но̄ mü öде; шћâ кýnum о̀вога̄ кӧња а не̂ма̄м па̂pā (Барјактаревић 1966: 127-128). Ипак, само у првом примеру конструкција се употребљава у значењу иреалног кондиционала за прошлост; у другом примеру глагол хтети употребљен је у свом основном значењу у имперфекту, са допуном и инфинитиву; док је у трећој у питању имперфекат глагола хтети којим се казују модалне радње које припадају садашњости, о којима ће бити речи у наредном одељку. Л. Вујовић као потврде потенцијала за прошлост такође наводи примере у којима се изриче радња која није остварена у прошлости с тим да последице њеног извршења не би биле негативне: дӓ је бйло кӥше, ћаิоме бӥт дӧбро (Вујовић 1969: 329-330). Значење иреалног кондиционала за прошлост које би одговарало нашој конструкцији шћаше + инфинитив у говору Мрковића исказује се аористом: $\partial a$ нё-би Исӓк, ӧн-га ӧдра. (Вујовић 1969: 329-330). У говору Враке употребљава се имати, у значењу „замало”: имӓк се пома̄мйт да нё дође (Петровић 1974: 175), а у истој служби овај глагол бележен је и у староцрногорским говорима (Пешикан 1965: 206). Исту функцију у мрковићком говору врши и глагол моћи: мӧга̄ме чӧвек изгўбит глаิву, да нё бй на̂с (Вујовић 1969: 128). Заменљивост глагола хтети поменутим глаголима могућа је и у нашем говору.

Нешто ређе ова конструкција бележи се у говорима херцеговачко-крајишког дијалекта. У Колашину оћаг + инфинитив користи се у значењу

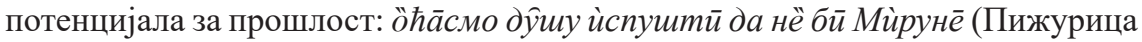
1981: 209). У ускочком говору ову службу врши глагол имати: ѝмаг у̀мријети (Станић 1977: 86). 
За говор Трстеника Д. Јовић наводи да је овај тип имперфекта употребљен у примерима као што су: ћа́мо да пренёсемо ал нё даде кӥша; ћа́ше да пропӓднеш да нё беше Рӓдивоја (Јовић 1968: 205), притом и овде сматрамо да у првом наведеном примеру није посреди конструкција са специјализованим значењем већ имперфекат глагола хтети у основној служби .

У говору Бучума и Белог Потока бележи се аорист који се употребљава и као потенцијал за исказивање иреалне прошле радње: да не купи́ коса́чииу још за пр́ви ма́j, пропа́dе се́но (Богдановић 1979: 122), док имперфекта употребљеног за иреалну прошлу радњу нема (Богдановић 1979: 123). Исто важи и за Алексиначко Поморавље, где се аорист употребљава и за исказивање иреалне прошле радње као потенцијалне: да ме не до́везе, пресná ja y Нúm (Богдановић 1987: 250), а за исказивање неизвршених прошлих радњи у перфирастичним конструкцијама иреалног кондиционала употребљава се имперфекат глагола хтети: ја ћа да поги́нем (Богдановић 1987: 250).

Имперфекат у кондиционалним реченицама П. Ивић бележи у галипољском говору: ако мӧга̄mе, ћâз да прิне (Ивић 1957: 369). Плусквамперфекат у служби иреалног кондиционала: јӧш идаิмnуm да бё ву фррјӥли, ћаิву да извӓдеју (= извадили би) по́nу. Ама не ктёиме (Ивић 1957: 373). Ван конструкције иреалног кондиционала, сложени облик са ћав (ћac) долази у потенцијалном значењу, обично са нијансом „замало”: ћаз д-ӥмре, ама повра тӥли га (Ивић 1957: 382).

У говорима шумадијско-војвођанског дијалекта ове конструкције нису биле забележене.

У поређењу са конструкцијом твореном од глагола бити и допунског глагола, у којој, као што је показано имамо став неслагања са чињеницом да се одређена радња у прошлости није (из)вршила, конструкција са глаголом хтети има супротну семантику. Наиме, како истиче љ. Поповић, а што одговара и нашим запажањима, ,ако конструкција са глаголом бити описује ситуацију са аспекта неповољне последице за коју је, по мишљењу говорног лица, крив саговорник који није поступио у складу са говорниковим назорима (или треће лице), друге две (има + инфинитив и (w)ћax + инфинитив) описују ситуацију у прошлости с аспекта, најчешће, повољне последице за коју је одговорно треће лице или се тај исход приписује изненадној околности која је спречила неповољни развој ситуације” (Поповић 2019: 211). Ипак, „у сва три случаја конструкција је контрафактивна - описана је претпостављена ситуација која припада прошлости II степена кроз призму ситуације из прошлости I степена - неповољне или повољне са тачке гледишта говорног лица. Оцена ситуације у прошлости І степена износи се у тренутку који припада времену говорне ситуације" (Исто).

\footnotetext{
${ }^{6}$ Иако у литератури нема података о осталим говорима косовско-ресавског дијалекта, поуздано (на основу разговора са колегама чији је ово матерњи идиом) знамо да се оне у говору често користе.
} 


\section{2. Хтети + инфинитив / да + презент са значењем садашњости (жељь, намера)}

Иако се имперфектом превасходно казују прошле радње, глагол хтети употребљен у овом облику са допуном у виду другог глагола у форми инфинитива или конструкције $\partial a+$ презент (у овом случају чешћом од инфинитива) може обележити дејства која се одликују садашњом временском перспективом $^{7}$, а у којима доминира модална компонента жеље или пак намере. У примерима типа: шћасмо купит мало брашна нису посреди дејства реализована у прошлости, нити радње иреалног кондиционала (иако се облички поклапају), већ су у питању експлициране радње које говорно лице изриче као намеру, жељу, план који постоји у садашњем тренутку, а који има / жели реализовати у (непосредној, скоријој) будућности. Семантички најблискији еквиваленти конструкцији у наведеним примерима били би презент или потенцијал (хоћу да те питам; хтео бих да те питам). Разлика према потенцијалу и презенту јесте у постојању додатне семантичке компоненте. Како је утврдио А. Пецо, имперфекат глагола хтети у овим примерима исказује радњу у чији исход говорно лице није сигурно. И баш због тога што радња још није реализована, што постоји нека бојазан у њен коначни завршетак њена реализација не зависи само од говорника, него и од неке више силе, те ту имперфекат има модално значење (Пецо 2007: 268). И Д. Јовић констатује да је овде реч о ублажавању, те да је вероватно оваква употреба имперфекта настала у времену када су услови живота били несигурнији, па је постојала опрезност у исказивању намера - „из страха да се не урече” (Јовић 1968: 204).

У нашој грађи су забележени примери са имперфектом (8), мада се глагол хтети каткад може јавити и у форми аориста (9). Када се намера препознаје из контекста, допунски глагол не мора бити експлициран (10):

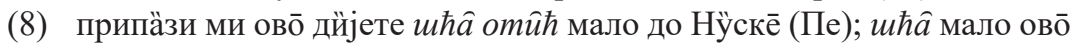

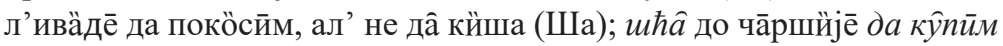
неке̄ грабӱље (Ле);

(9) ђё ти је маิјка, хтёдо нёшто да јој каิжемм (По); äј сӓ мно̄м, хтёдо до продаิвнице̄ да ӱзмём нешто (Ру);

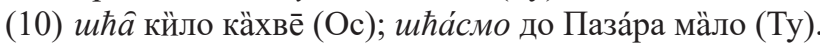

Уместо глагола хтети у истој служби и са истим значењем могу се употребити и други глаголи (11):

(11) мӧга̄смо посёдет још мӓло (По); мйшьь $\bar{a}$ да се окŷnа̄м (По); имаิх нешто паิра̄ па̄ реко да куิпйм нёшто (С. До); трёба̄ще ми нешто да күิпйм о́де (Бо).

У Бјелопавлићима су забележени примери типа: ӧћа̄ нёшто да ти напомеิнём; у којима се износе потенцијалне радње, дакле условне, које имају модални карактер (Ћупић 1977: 168). У говору Црмнице имперфекат глагола

\footnotetext{
${ }^{7} \mathrm{O}$ употреби имперфекта за означавање радњи које се додирују са моментом садашњости детаљније у: Стевановић 1986: 661-662; Вуковић 1967: 126-128.
} 
шћет у вези са инфинитивом такође значи жељу или намеру како у садашњости, тако и у прошлости и будућности: а) ћаิк ви рёћ нёшто, ма ми нёћете

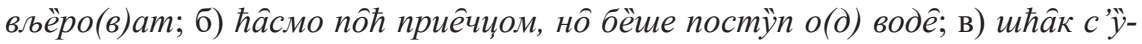
mpa (nôћ) нӓ Вӣp (Милетић 1940: 552-553). Исту семантику има и у говору Враке: Öћāк и ја̂ нёшто рёћ, где се бележи и глагол мислити у истој служби (Петровић 1974: 175). А тако је и у Мрковићима: Бећӥре, ӥмаше ли дуваิна? (Вујовић 1969: 332-333). Д. Барјактаревић такође бележи ову конструкцију: Шћâ кýnит о̀вога̄ кӧња а немма̄м па̂ра̄ (Барјактаревић 1966: 127-128).

У источној и централној Херцеговини бележено је: шћаิк нешто бра́ва̄ ши́mат (већ је дошла да их шиша) (Пецо 2007: 268). У Колашину се бележи: a) оћаг + инфинитив у намерним и намерно-узрочним реченицама: прѝпази ми оิвце - öћаг јâ òmūc да про̀пūpūм вӓтру; б) оћаг + инфинитив у типичном модалном значењу: ӧћа̄смо ти нёшто по̀нудйm (Пижурица 1981: 210). За говор Пиве и Дробњака Ј. Вуковић констатује да „глаголи шћети (хтети), требати, моћи, морати, бити, имати, вољети, радити, мислити, намеравати (у значењу хтети учинити) имају поред обичне и посебну употребу имперфекта у овом говору - у значењу неке врсте презента у неком модалном значењу или у значењу жељног потенцијала. Зато се увек у том случају могу и

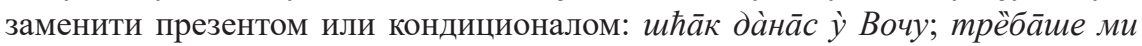
јӧш мало жӥта" (Вуковић 1940: 88).

Д. Јовић истиче да је потреба исказана у примеру - требаше ми та нож - везана несумњиво за тачку с а д а. Али и да је исказ је резултат потребе настале раније (Јовић 1968: 204).

У говору Бучума и Белог Потока: треба́ше да и́дем у Сврљи́г по критени́иу (Богдановић 1979: 123).

\section{3. Хтети + инфинитив / да + презент у квалификативној служби}

Ова конструкција није честа у говору Тутина, Новог Пазара и Сјенице као претходно анализиране јер домен њене употребе већим делом покрива конструкција би + императив (в. т. 1.2.). Њоме се исказују у прошлости понављане радње које су, због учесталог вршења, постале трајном особином лица о коме је реч те добиле квалификативни карактер. Обичнија је допуна $\partial a+$ презент (12) него у инфинитиву (13):

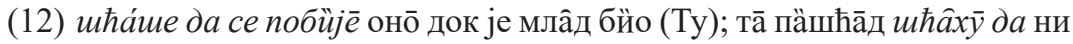

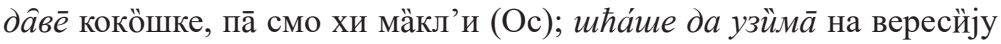
стаิлно (Пе);

(13) сӓмо шћа́ше кйкат, по цйо даิн (Ле).

Податке о овој конструкцији пронашли само у студији о говору Колашина, где се наводи да се употребљава оћаг + инфинитив у хабитуалном

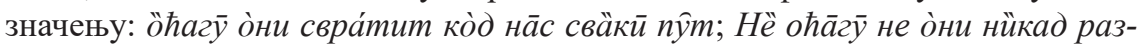
ми́нут. Уместо инфинитива може се чути, врло ретко, императив: ӧћагу о̀ни до́ђи па с’ёди (Пижурица 1981: 210). 


\section{Закључак}

Спроведена анализа показала је да се конструкција било + инфинитив користи за исказивање радње које се у прошлости нису (из)вршиле а које је требало (из)вршити како би се спречиле последице које су уследиле; тј. радње које није требало (из)вршити јер би се тако могле спречити последице које су услед тога наступиле. Конструкција са истим значењем фреквентна је у свим јекавским говорима, док на остатку штокавштине није бележена.

Конструкција би + императив у испитиваном говору има вредност специјализованог језичког средства за исказивање хабитуалне семантике. До нашега истраживања и литератури је била позната искључиво као синтаксема бележена у говорима на територији БиХ.

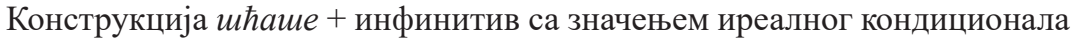
употребљава за обележавање радње која се у прошлости умало извршила, али ипак, на срећу, није, чиме су спречене озбиљније последице. Морфолошки иста конструкција употребљава се и у квалификативном значењу те у модалној служби исказивања жеље или намере. Ове конструкције познају сви јекавски говори.

\section{ЛИТЕРАТУРА}

Барјактаревић 1966: Д. Барјактаревић, Новопазарско-сјенички говори, Српски дијалектолошки зборник, XVI, 1-177.

Богдановић 1979: Н. Богдановић, Говори Бучума и Белог Потока, Српски дијалектолошки зборник, XXV, I-XIV + карта + 1-178.

Богдановић 1987: Н. Богдановић, Говор Алексиначког Поморавља, Српски дијалектолошки зборник, XXXIII, 7-302.

Брозовић 1958: D. Brozović, Izvještaj o dijalektološkim istraživanjima u srednjoj Bosni, Ljetopis Jugoslavenske akademije znanosti $i$ umjetnosti za godinu 1958, knj. 65, Zagreb: Jugoslavenska akademija znanosti i umjetnosti, 334-351: http://dizbi.hazu.hr/index.php?search=2\&paging=1\&query=ljetop is +jugoslavenske+akademije+knjiga+65. 15.11.2013.

Вујовић 1969: Л. Вујовић, Мрковићки дијалекат (с кратким освртом на сусједне говоре), Српски дијалектолошки зборник, XVIII, 73-398 (с картом).

Вуковић 1940: Ј. Вуковић, Говор Пиве и Дробњака, Јужнословенски филолог, XVII, 1-113.

Вуковић 1954: Ј. Вуковић, Модални облици с имперфектом глагола бити + инфинитив главног глагола, Јужнословенски филолог, ХХ, 1-4, $263-272$.

Вуковић 1967: Ј. Вуковић, Синтакса глагола, Сарајево: Завод за издавање уџбеника. 
Грицкат 1998: И. Грицкат, Потенцијал у служби исказивања хабитуалности - и неколико напомена поводом ове конструкције, Јужнословенски филолог, LIV, 35-40.

Ибришимовић 2011: N. Ibrišimović, Neke osobitosti upotrebe imperativa u romanu Vječnik, Motrišta: glasilo Matice hrvatske, br. 59-60, Mostar: „SHIFT kreativna agencija”, 35-42.

Ивић 1957: П. Ивић, О говору Галипољских Срба, Српски дијалектолошки зборник, XII, XXI + 1-519.

Ивић 2001: П. Ивић, Дијалектологија српскохрватског језика. Увод и штокавско наречје, Сремски Карловци - Нови Сад: Издавачка књижарница Зорана Стојановића.

Ивић М. 1983: М. Ивић, Начини на које словенски глагол овремењује понављану радњу, у: Лингвистички огледи, Београд: Библиотека XX век, $37-56$.

Јовић 1968: Д. Јовић, Трстенички говор, Српски дијалектолошки зборник, XVII, XVI + 1-238 + карта.

Лучић 2008: R. Lučić, Oblik kondicionala u funkciji ponavljane radnje u prošlosti, Croatica et Slavica Iadertina, vol. 4, no. 4, Zadar: Sveučilište u Zadru, 7-21: < http://hrcak.srce.hr/index.php?show=clanak\&id_clanak_jezik=51899. 14.11.2013.

Милетић 1940: Б. Милетић, Црмнички говор, Српски дијалектолошки зборник, IX, 209-663.

Николић 1972: М. Николић, Говор Горобиља (код Ужичке Пожеге), Српски дијалектолошки зборник, XIX, 619-746.

Окука 2008: М. Окука, Српски дијалекти, Загреб: Српско културно друштво „Просвјета".

Петровић 1974: Д. Петровић, Из синтаксичке проблематике говора Врачана, Годишьак Филозофског факултета у Новом Саду, XVII/1, 161-183.

Пецо 2007: А. Пецо, Говори источне и иентралне Хериеговине, Сарајево: Босанско филолошко друштво, 1-434.

Пешикан 1965: М. Пешикан, Староцрногорски средњокатунски и љешански говори, Српски дијалектолошки зборник, XV, VIII + 1-294.

Пижурица 1981: М. Пижурица, Говор околине Колашина, Титоград: Црногорска академија наука и умјетности.

Поповић 2019: Љ. Поповић, О једној посебној контрафактивној конструкцији у српском језику, Наш језик, L/2, 205-219.

Станић 1977: М. Станић, Ускочки говор II, Српски дијалектолошки зборник, XXII, 1-157.

Стевановић 1986: М. Стевановић, Савремени српскохрватски језик II, Београд: Научна књига.

Стојановић 1921: Љ. Стојановић, О значењу и употреби глаголских облика у реченицама, Јужнословенски филолог, II, 187-210.

Тешић 1977: М. Тешић, Говор Љештанског, Српски дијалектолошки зборник, XXII, 159-328. 
Ћирић 1983: Љ. Ћирић, Говор Лужнице, Српски дијалектолошки зборник, XXIX, 7-190.

Ћупић 1977: Д. Ћупић, Говор Бјелопавлића, Српски дијалектолошки збор$н и к$, XXIII, IX + 1-226.

Халиловић 1985: С. Халиловић, Хабитуал у штокавском дијалекту, Кюижевност и језик, 32/1-2, 51-55.

\author{
Bojana Veljović
}

\title{
VERBAL CONSTRUCTIONS WITH BITI AND HTETI IN DIALECTS OF THE SERBIAN LANGUAGE
}

\section{Summary}

The paper analyzes complex verbal constructions which are comprised of biti and hteti in the first and auxiliary verbs in the second part. Constructions formed with the verb biti include: a) the aorist of the verb biti + imperative; b) the perfect form of the verb biti + infinitive. The verb hteti in the imperfect tense may be observed in three constructions which, although similar in form, have different meanings. All of the constructions belong to dialects and are not applicable to all speech varieties. The areal distribution depends on the systemic status of the forms which are used to create verbal constructions - imperfect, infinitive. Dialects in which these verb forms are on the verge of disappearing, or have in fact already disappeared do not recognize the constructions from which they were formed, while idioms in which the status of such forms is stable do recognize them. It has been determined that these forms are best preserved in the ijekavian speech of the Zeta-Sjenica and Eastern Herzegovinian dialect, while it is rarer in other territories.

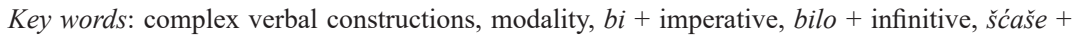
infinitive. 